\title{
PENAATAN PERUSAHAAN TAMBANG BATUBARA DI KALIMANTAN TIMUR TERHADAP PERATURAN AIR LIMBAH PERTAMBANGAN
}

\section{COAL MINING COMPANY COMPLIANCE IN EAST KALIMANTAN TO WASTE WATER REGULATIONS OF MINING}

\author{
Alfrida E. Suoth dan Ernawita Nazir ${ }^{1}$
}

(Diterima tanggal 30-11-2013; Disetujui tanggal 02-01-2014)

\begin{abstract}
ABSTRAK
Indonesia memiliki cadangan batubara yang tersebar di Pulau Kalimantan dan Pulau Sumatera, sedangkan dalam jumlah kecil, batu bara berada di Jawa Barat, Jawa Tengah, Papua dan Sulawesi. Seperti halnya aktifitas pertambangan lain di Indonesia, Pertambangan batubara juga telah menimbulkan dampak kerusakan lingkungan hidup yang cukup besar, baik itu air, tanah, udara, dan hutan. Pemantauan air limbah pada area pertambangan batubara dilakukan untuk mengetahui tingkat ketaatan industri terhadap baku mutu air limbah pertambangan yang dibuang ke lingkungan. Pemantauan dilakukan terhadap 6 (enam) perusahaan tambang batubara (kode A-F) yang berada di Kalimantan Timur- Indonesia. Contoh uji berupa air limbah yang berasal dari kegiatan penambangan dan pengolahan batubara. Pengukuran parameter dilakukan di lapangan dan di laboratorium. Hasil analisis yang didapat dibandingkan dengan Keputusan Menteri Lingkungan Hidup No. 113 Tahun 2003 tentang baku mutu air limbah pertambangan batubara. Berdasarkan pengukuran $\mathrm{pH}$ air limbah kegiatan pertambangan dan kegiatan pengolahan batubara, $\mathrm{pH}$ berada pada kisaran 4,2-10, sehingga nilai $\mathrm{pH}$ telah melebihi baku mutu yang dipersyaratkan dalam Kepmen-LH No. 113 Tahun 2003, yaitu 6 - 9. Konsentrasi parameter besi (Fe) ditemukan 76 mg/L di lokasi E-2, nilai ini melebihi baku mutu yang dipersyaratkan, yaitu: $7 \mathrm{mg} / \mathrm{L}$. Total Suspended Solid (TSS) di lokasi E-2 konsentrasinya $5304 \mathrm{mg} / \mathrm{L}$, melebihi baku mutu yaitu: $400 \mathrm{mg} / \mathrm{L}$. Konsentrasi mangan (Mn) masih memenuhi baku mutu disemua lokasi. Konsentrasi sulfat terdeteksi dalam kisaran $23-551 \mathrm{mg} / \mathrm{L}$, sedangkan parameter sulfida dan sianida secara umum nilainya masih di bawah limit deteksi metode.
\end{abstract}

Kata kunci: pemantauan, batu bara, baku mutu, kriteria mutu air, logam berat

\begin{abstract}
Indonesia has coal resources spread across the island of Kalimantan and Sumatra, while small amounts of coal in West Java, Central Java, Papua and Sulawesi. As with other mining activities in Indonesia, coal mining has also caused environmental damage is large enough in water, soil, air, and forests. Monitoring of waste water in the coal mining area was conducted to determine the level of adherence to the industry quality standard mining waste water discharged into the environment. Monitoring carried out on six (6) coal mining company (code A-F) which are in East-Kalimantan, Indonesia. The wastewater of the coal mining industries and its processingactivities were taken for analysis. Measurement parameters done in the field and in the laboratory. The results of the analysis were compared with the Minister of Environment Decree No. 113 of 2003 on wastewater quality standard coal mining. By measuring the $\mathrm{pH}$ of water and mining waste coal processing activities, the $\mathrm{pH}$ in the range 4.2 to 10 , therefore the $p H$ value has exceeded the quality standard required by the Decree-LH No. 113 In 2003, the 6-9. Concentration parameters of iron $(\mathrm{Fe}$ ) found $76 \mathrm{mg} / \mathrm{L}$ at location E-2, this value exceeds the required quality standards, $7 \mathrm{mg} /$ L. Total Suspended Solid (TSS) at the location of the E-2 concentration is $5304 \mathrm{mg} / \mathrm{L}$, which exceeded the quality standard: $400 \mathrm{mg} / \mathrm{L}$. The concentration of manganese (Mn) still meets the quality standards at all locations. The concentration of sulfate was detected in the range of $23-551 \mathrm{mg} / \mathrm{L}$, whereas the parameters sulfide and cyanide in general its value is still below the detection limit of the method.
\end{abstract}

Keywords: monitoring, coal, quality standard, water criteria, heavy metals.

\footnotetext{
${ }^{1}$ Pusarpedal-KLH Kawasan Puspiptek Gedung 210 Jalan Raya Puspiptek Serpong, Tangerang Selatan. Email : idasuoth@gmail.com
} 


\section{PENDAHULUAN}

Pengendalian pencemaran lingkungan merupakan salah satu bentuk implementasi mandatori dari Undang- Undang Nomor 32 Tahun 2009 tentang Perlindungan dan Pengelolaan Lingkungan Hidup, yaitu pengendalian pencemaran dan/atau kerusakan lingkungan hidup dilaksanakan dalam rangka pelestarian fungsi lingkungan hidup [1]. Untuk memenuhi mandat UU No. 32 tahun 2009, Pusarpedal sebagai unit teknis Kementrian Lingkungan Hidup, melakukan pemantauan di lokasi pertambangan batubara dengan tujuan mengetahui kualitas air limbah usaha/kegiatan pertambangan batubara yang berada di Kalimantan Timur serta menyediakan data yang dapat digunakan untuk menentukan kebijakan pengelolaan lingkungan hidup berkelanjutan yang terkait dengan pertambangan batubara.

Batubara adalah bahan bakar hidrokarbon padat yang terbentuk dari tetumbuhan dalam lingkungan bebas oksigen dan terkena pengaruh panas serta tekanan yang berlangsung lama[2]. Batubara merupakan salah satu bahan galian strategis yang sekaligus menjadi sumber daya energi yang sangat besar. Kegiatan pertambangan di Indonesia berkembang secara signifikan pada awal tahun 1970-an yang dipicu oleh masuknya investor pertambangan dunia dan semakin berkembangnya tenaga ahli pertambangan Indonesia[3].

Indonesia mempunyai potensi sumberdaya batu bara sangat melimpah, terletak di bagian barat Paparan Sunda (termasuk Pulau Sumatera dan Kalimantan). Daerah-daerah lainnya yang juga dapat dijumpai batubara adalah di Jawa Barat, Jawa Tengah, Papua, dan Sulawesi. Sistem penambangan batubara yang ada di Indonesia umumnya dilakukan dengan cara tambang terbuka. Sistim tambang terbuka dilakukan dengan cara penebangan atau pembukaan hutan yang diikuti pengangkatan ataupun pembuangan lapisan atas tanah (top soil). Proses penambangan batubara terdiri atas beberapa tahap sebagai berikut[4]:

\section{Tahap 1. Pengupasan Lapisan Tanah Penutup(Overburden).}

Pada tahap ini lapisan tanah bagian atas dikupasyaitu tanah sebelum lapisan batubaratermasuk lapisan topsoil.

\section{Tahap 2. Proses Pengambilan Batubara / Coal Getting.}

Setelah lapisan batubara terbuka,langsung dilakukan pengambilan batubara(coal getting)

Tahap 3. Penumpukan Batubara di Lokasi Pelabuhan Muat.

Batubara yang diangkut dari lokasi tambang dibongkar di lokasi pelabuhan muat yang disebut ROM (Row Of Material) Stockpile.

Tahap 4.Proses penghancuran batubara (crushing) dan /atau Pencucian Batubara (Washing).

Penghancuran batubara sesuai dengan spesifikasi yang ditentukan. Apabila diperlukan, dapat dilakukan pencucian batubara untuk memperbaiki/meningkatkan kualitas batubara tersebut.

\section{Tahap 5. Pemuatan Batubara ke Dalam} Tongkang.

Sized coal (batubara curah) diambil lalu dimasukkan kedalam tongkang yang menggunakan loading conveyor lalu siap untuk pengiriman antar pulau atau transshipment ke mother vessel. 

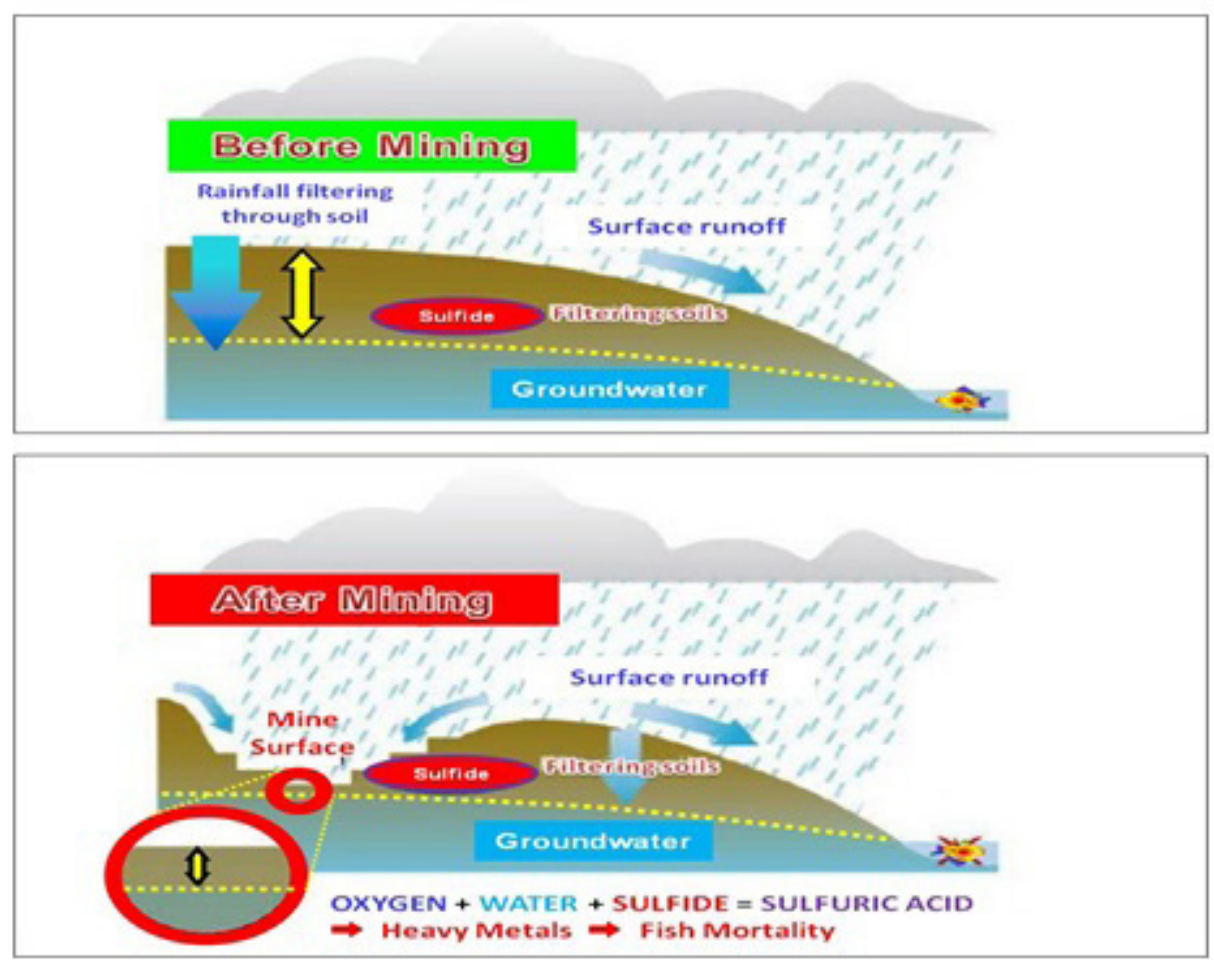

Gambar 1. Kondisi Area Pertambangan Sebelum dan Sesudah di lakukan Kegiatan Pertambangan[5]

\section{Tahap 6. Menuju ke Alat Angkut Utama}

Tongkang yang sudah siap akan di tarik oleh kapal tunda (Tug Boat) menuju kapal angkut utama (Mother Vessel). Setelah proses loading selesai kapal siap di berangkatkan ke pulau dan atau negara tujuan.

kegiatan tahap 1 (pengupasan lapisan tanah/ overburden) pada proses pertambangan batubara memungkinkan terbentuknya air asam tambang. Air asam tambang atau AAT adalah istilah yang digunakan untuk menyebutkan rembesan atau aliran air yang terjadi akibat adanya reaksi antara air permukaan, baik air limpasan hujan maupun genangan air, dengan lapisan batuan yang mengandung mineral belerang. Mineral belerang yang paling umum ditemukan adalah Pyrite (FeS)[6].

Pertambangan batubara mempunyai dua sisi, yaitu sebagai pemicu kemakmuran ekonomi dan sisi lainnya sebagai sesuatu yang berpotensi menimbulkan dampak terhadap lingkungan diantaranya adalah masalah kerusakan struktur tanah dan tata air, menurunnya kualitas perairan serta menurunnya kualitas udara. Terkait dengan kerusakan lahan, telah terjadi indikasi daerahdaerah bekas pertambangan akan terbentuk lubang-lubang bekas tambang yang tidak dapat lagi di tutup atau dikembalikan seperti semula.

\section{METODOLOGI}

\section{Waktu dan tempat penelitian}

Penelitian dilaksanakan di laboratorium Air Pusat Sarana Pengendalian Dampak Lingkungan (Pusarpedal), Jalan Raya Puspiptek Gedung 210, Serpong, Tangerang Selatan 15314. Waktu penelitian dilakukan selama 6 (enam) bulan terhitung sejak Maret 2012 sampai dengan Agustus 2012. 


\section{Lokasi Pengambilan Contoh Uji}

Pengambilan contoh uji dilakukan pada 6 (enam) pertambangan batubara yang berlokasi di Kalimantan Timur. Pengambilan contoh uji meliputi air limbah dari kegiatan penambangan batubara. Lokasi pengambilan contoh uji dapat dilihat pada gambar 2 dan 3 berikut ini.

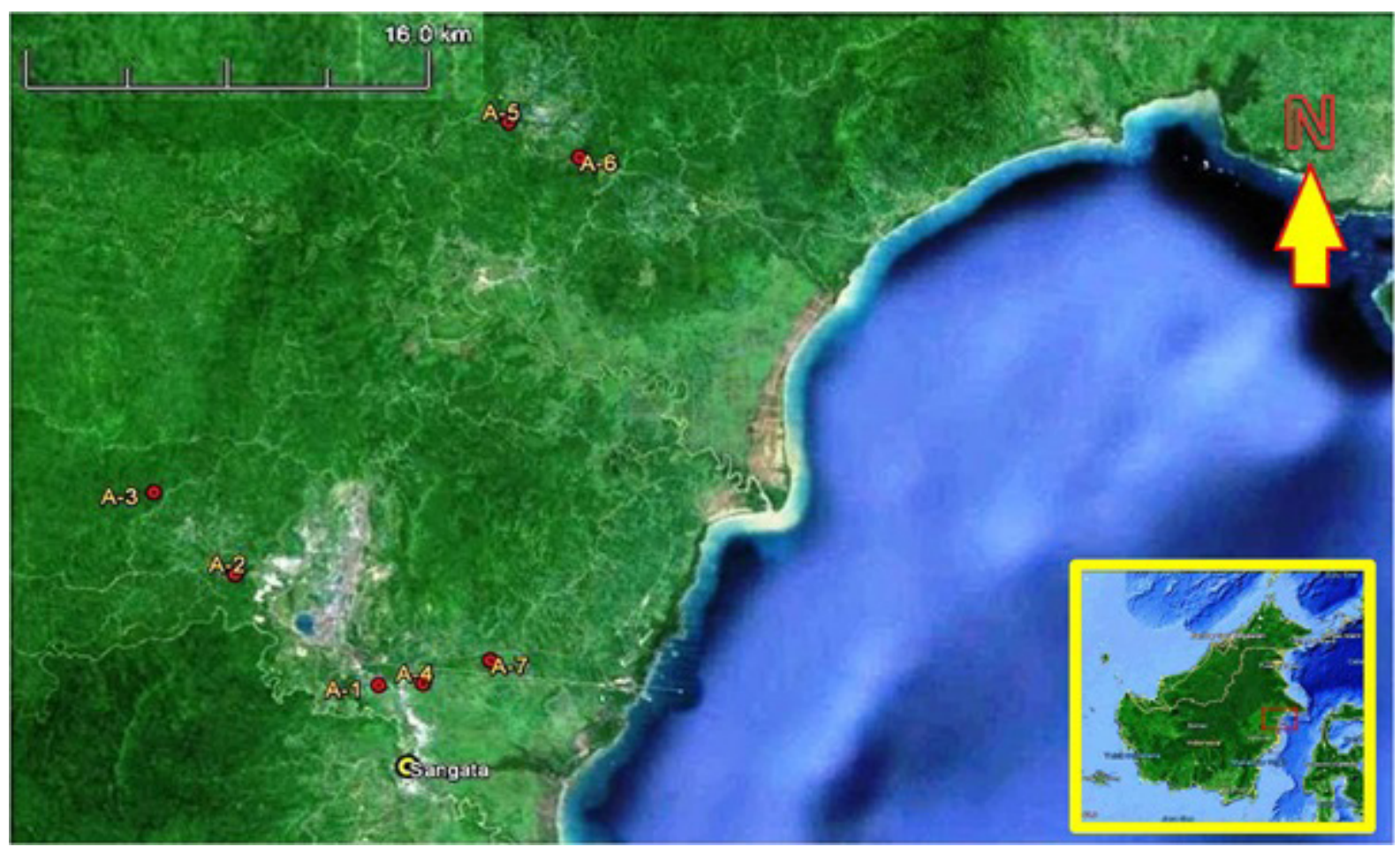

Gambar 2. Lokasi pengambilan contoh uji di Kalimantan Timur (lokasi A)

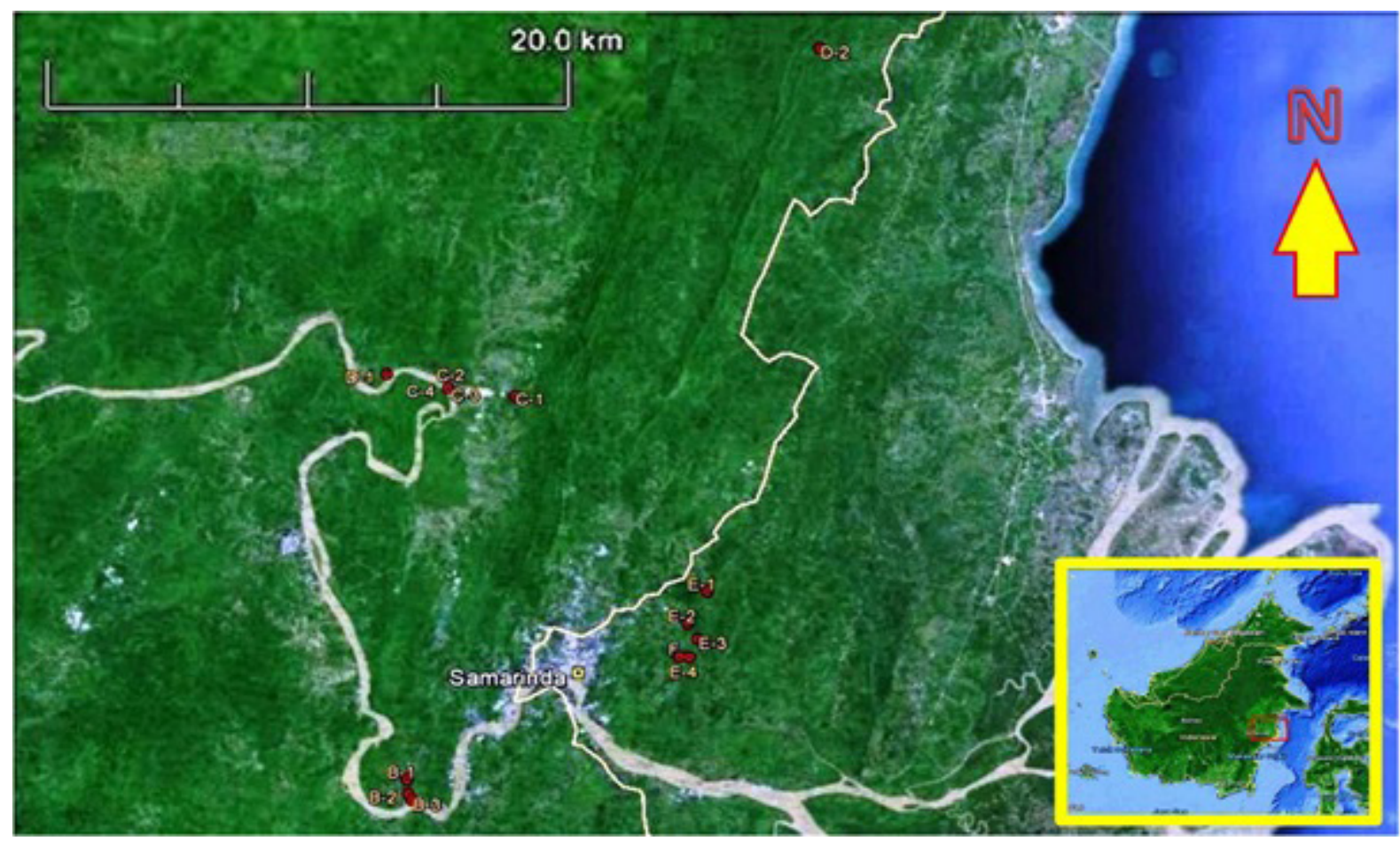

Gambar 3. Lokasi pengambilan contoh uji di Kalimantan Timur (lokasi B-F) 


\section{Parameter}

Contoh uji air limbah yang berasal dari kegiatan pertambangan batubara diambil guna mengetahui kandungan logam total dan parameter anorganik lainnya. Parameter yang dianalisa adalah: Besi (Fe), Mangan $(\mathrm{Mn})$, Tembaga $(\mathrm{Cu})$, Cadmium $(\mathrm{Cd})$, Timbal $(\mathrm{Pb})$, Seng ( $\mathrm{Zn})$, Chromium (Cr), Selenium (Se), Arsen (As), Nikel (Ni), Cobal (Co), Merkuri (Hg) dan parameter lainya yaitu pH, Temperatur, Daya Hantar Listrik (DHL), Total Suspended Solid (TSS), Total Dissolved Solid (TDS), Sulfat (SO4), Sulfida $(\mathrm{S}=)$, Total Nitrogen, Amoniak (NH3N), dan total Sianida $(\mathrm{CN})$.

\section{Pengambilan Contoh Uji Air Limbah}

Pemilihan titik sampling dilakukan berdasarkan pertimbangan sebagai berikut :
1. Titik penaatan/titik sampling pemantauan dari perusahaan pertambangan;

2. Pond/kolam penampungan air limbah pertambangan

3. Kegiatan sekitar pertambangan batubara

4. Berdasarkan kondisi yang dianggap perlu untuk pemantauan;

Contoh uji air limbah berasal dari limbah kegiatan pertambangan yang sudah diolah maupun yang belum diolah. Pengambilan contoh uji air limbah mengacu ke SNI 6989.59.2008[7].

\section{Metode Analisis}

Analisis Air limbah pertambangan dilakukan oleh Laboratorium Air Pusarpedal dengan menggunakan metode yang tertera di bawah ini :

Tabel 1. Metode Analisis Air Limbah

\begin{tabular}{c|c}
\hline Parameter & Metode \\
\hline pH & SNI 06-6989-11-2004 \\
Temperatur, suhu & Standard Methods-APHA 2550-2005 \\
Total padatan terlarut, TDS & SNI 06-6989-1-2004 \\
Total Suspended Solid, TSS & SNI 06-6989.27-2005 \\
Sulfida & SNI 06-6989-3-2004 \\
Sulfat & Standard Methods-APHA 4500-S2- \\
Sianida & SNI 19-6964.5-2005 \\
Total Nitrogen & SNI 19-6964.6-2003 \\
Amoniak, NH3N & JIS K.0102-45.2-2002 \\
Besi, Fe & Standard Methods-APHA \\
Mangan, Mn & 4500NH3-F,2005 \\
Merkuri, Hg & Standard Methods-APHA 3111B-2005 \\
Tembaga, Cu & Standard Methods-APHA 3111B-2005 \\
& Standard Methods-APHA 3112B-2005 \\
& Standard Methods-APHA 3111B-2005 \\
\hline
\end{tabular}




\section{HASIL DAN PEMBAHASAN}

Hasil analisa air limbah yang berasal dari 6 perusahaan tambang batubara yang berada di Kalimantan Timur dibandingkan dengan Kepmen-LH tentang bakumutu air limbah bagi usaha atau kegiatan pertambangan batubara yang mengatur airlimbah yang berasal dari kegiatan penambangan dan pengolahan/ pencucian batubara.

Pengukuran $\mathrm{pH}$ yang dilakukan di lokasi pertambangan yang berada di propinsi Kalimantan Timur menunjukkan masih ada air limbah yang belum memenuhi kriteria Kepmen-LH yang dipersyaratkan yaitu 6 - 9. Nilai $\mathrm{pH}$ bersifat asam/rendah masih ditemukan di Outlet B-1 $(4,2)$ dan run off B-3 $(4,8)$ namun di lokasi preeplant B-2 di peroleh nilai $\mathrm{pH}$ sudah normal $(7,0)$. Air limbah dengan nilai $\mathrm{pH}$ yang rendah/asam akan semakin memudahkan logam-logam yang terkandung didalamnya untuk melarut sehingga mengakibatkan kandungan logam dalam contoh uji tersebut meningkat.

$\mathrm{pH}$ diatas 9 menandakan contoh uji cenderung bersifat basa, $\mathrm{pH} 10$ ditemukan di pertambangan D-1 yang merupakan pond penampungan air yang berasal dari limpasan kegiatan crusher demikian jugadi lokasi $\mathrm{F}$ nilai $\mathrm{pH}$ terukur 10. Ada berbagai macam pengolahan air limbah pertambangan, salah satu pengolahan yang mudah dan praktis adalah dengan penambahan kapur. Penambahan kapur perlu di perhitungkan perbandingannya dengan volume air limbah agar supaya bisa diperoleh keseimbangan proses reaksi antara air limbah dan kapur, diharapkan nilai pH

Tabel 2. Data Hasil Analisis Air Limbah Pertambangan Batubara Kaltim

\begin{tabular}{c|c|c|c|c}
\hline Lokasi & $\mathrm{pH}$ & $\mathrm{TSS}(\mathrm{mg} / \mathrm{L})$ & $\mathrm{Fe}(\mathrm{mg} / \mathrm{L})$ & $\mathrm{Mn}(\mathrm{mg} / \mathrm{L})$ \\
\hline A-1 & 7,7 & 36 & 1,1 & 0,43 \\
$\mathrm{~A}-2$ & 7,5 & 10 & 0,26 & 0,78 \\
$\mathrm{~A}-3$ & 7,3 & 2 & 0,18 & 0,55 \\
$\mathrm{~A}-4$ & 7,0 & 17 & 0,68 & 1,1 \\
$\mathrm{~A}-5$ & 8,2 & 26 & 1 & 3,5 \\
$\mathrm{~A}-6$ & 6,9 & 5 & 0,14 & 1,5 \\
$\mathrm{~A}-7$ & 6,9 & 24 & 1,1 & 1,4 \\
$\mathrm{~B}-1$ & 4,2 & 10 & 1,1 & 2,9 \\
$\mathrm{~B}-2$ & 7,0 & 23 & 1,6 & 0,23 \\
B-3 & 4,8 & 16 & 1,7 & 1,4 \\
C-1 & 6,0 & 36 & 0,44 & 0,010 \\
C-2 & 7,0 & 5 & 0,77 & 0,034 \\
C-3 & 7,4 & 9 & 0,41 & 0,025 \\
D-1 & 10 & 44 & 0,31 & 0,038 \\
D-2 & 7,2 & 28 & 0,49 & 0,15 \\
E-1 & 7,8 & 70 & 2,1 & 0,25 \\
E-2 & 7,2 & 5304 & 76 & 0,71 \\
E-3 & 7,1 & 68 & 3,6 & 0,28 \\
E-4 & 6,8 & 10 & 0,95 & 0,58 \\
F & 10 & 90 & 1,8 & 0,25 \\
Bakumutu* & $6-9$ & 400 & 7 & 4 \\
\hline
\end{tabular}

*) Keputusan Mentri Lingkungan Hidup No. 113 tahun 2003 


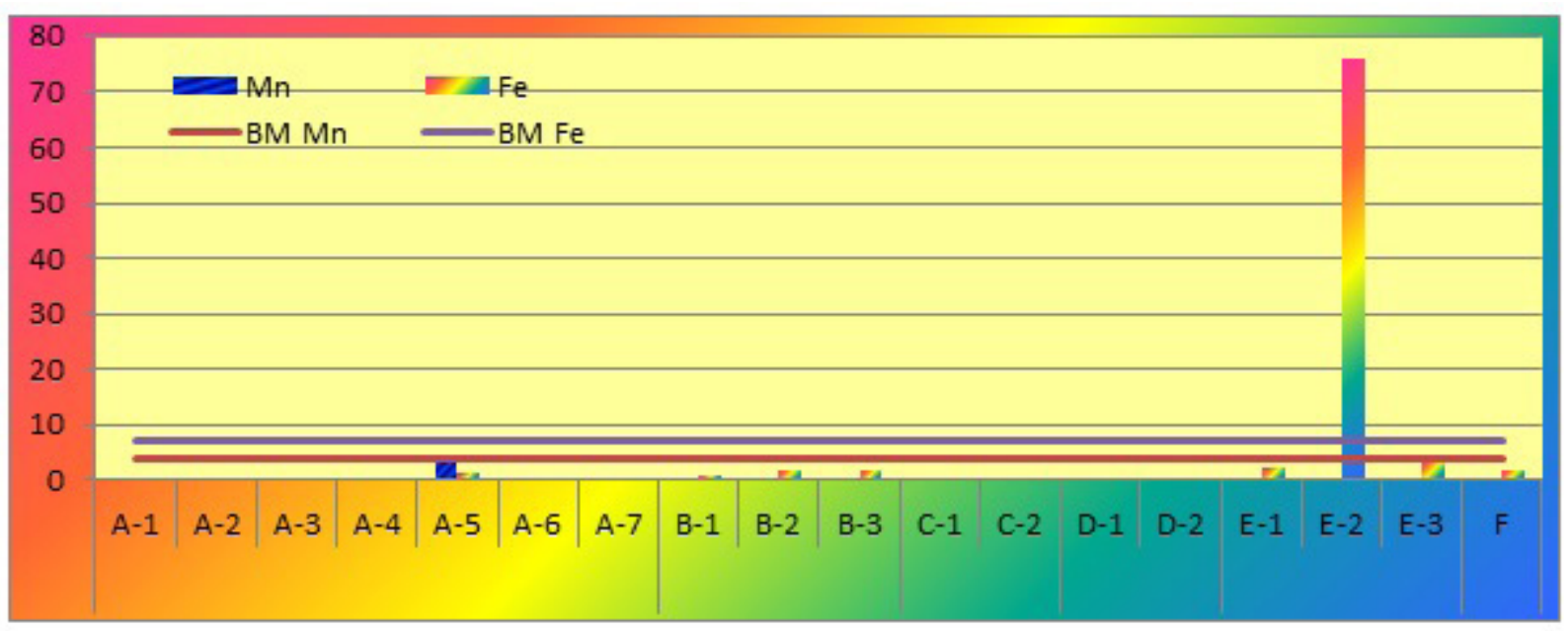

Gambar 4. Grafik Konsentrasi Besi dan Mangan Air Limbah Kegiatan Penambangan dan Kegiatan Pengolahan Batubara di Kalimantan Timur

setelah pengolahan berada pada rentang yang di persyaratkan Kepmen-LH.

Konduktivitas (Daya Hantar Listrik/DHL) adalah gambaran numerik dari kemampuan air untuk meneruskan aliran listrik. Oleh karena itu semakin banyak garam-garam terlarut yang dapat terionisasi, semakin tinggi pula nilai DHL. Nilai DHL pada semua lokasi sampling air limbah berada pada kisaran 219$2445 \mu \mathrm{S} / \mathrm{cm}$ sedangkan nilai TDS berada pada range 33-1235 mg/L, Nilai DHL berbandinglangsungdengan nilai TDS.

Konsentrasi besi dalam air limbah pertambangan yang di persyaratkan adalah 7 $\mathrm{mg} / \mathrm{L}$, hampir semua air limbah yang berasal dari lokasi sampling Kaltim berada di bawah baku mutu yang dipersyaratkan kecuali untuk lokasi E-2 (76 mg/L). Kondisi air limbah di lokasi E-2 berwarna keruh dan berlumpur, keadaan ini juga mengakibatkan nilai TSS $5304 \mathrm{mg} / \mathrm{L}$. Logam dapat terikat dengan suspended solid dan apabila perairan dalam kondisi asam maka logam tersebut dapat terlepas ikatannya dan bisa mengakibatkan konsentrasi logam meningkat.

Mangan dalam air limbah pertambangan di Provinsi Kaltim berada di bawah baku mutu yang dipersyaratkan. TSS yang dipersyaratkan dalam kepmen-LH adalah $400 \mathrm{mg} / \mathrm{L}$. Konsentrasi TSS diatas baku mutu $(5304 \mathrm{mg} / \mathrm{L})$ terdeteksi di lokasi E-2. Nilai TSS yang tinggi diakibatkan terikutnya/ terbawanya lapisan tanah yang sudah dalam kondisi terbuka akibat aktifitas pertambangan oleh air hujan. Kegiatan pengolahan/pencucian batubara adalah proses peremukan, pencucian, pemekatan dan atau penghilangan batuan/ mineral pengotor atau senyawa belerang dari batubara tanpa mengubah sifat kimianya [2]. Tujuan pencucian batubara guna mengurangi sulfur batubara akibatnya sulfur akan terlarut kedalam air limbah.

Nilai TSS berkorelasi secara langsung dengan kekeruhan. TSS yang tinggi sangat menggangu perikanan bila nantinya akan di buang ke lingkungan terutama ke sungai, dapat mengganggu kehidupan biota perairan. Kekeruhan yang tinggi mengakibatkan terganggunya sistem osmoregulasi, misalnya pernafasan dan daya lihat organisme akuatik [8].

Parameter anorganik yang dianalisa yaitu sulfida, sulfat, sianida, total nitrogen dan amoniak.

Secara umum nilainya rendah bahkan ada yang dibawah limit deteksi metode, hal ini berbeda 
dengan parameter sulfat yang di semua lokasi terdeteksi, namun ada juga contoh uji yang tidak bisa di analisa dikarenakan kekeruhan yang sangat tinggi. Konsentrasi sulfat berkisar 23 - $551 \mathrm{mg} / \mathrm{L}$ di lokasi pertambangan di provinsi Kaltim.

Logam $\mathrm{Hg}, \mathrm{Cu}, \mathrm{Cd}, \mathrm{Pb}, \mathrm{Zn}, \mathrm{Cr}$, Se, As, Ni dan Co dalam air limbah yang berasal dari kegiatan pertambangan maupun kegiatan pengolahan batubara secara umum nilainya kecil bahkan ada yang dibawah limit deteksi metode.

\section{SIMPULAN}

1. Hasil analisis air limbah pertambangan dari 6 (enam) lokasi pertambangan di Kalimantan Timur dibandingkan dengan KepMn LH No.113 tahun 2003 lampiran 1 , adalah :

a. Parameter $\mathrm{pH}$ melebihi baku mutu di perusahaan B yaitu titik B-1 dan B-2 serta perusahaan F.

b. Parameter Fe dan TSS melebihi Kepmen-LH di lokasi pertambangan E-2.

c. Parameter Mangan di seluruh pertambangan yang dipantau masih memenuhi Kepmen-LH No. 113 tahun 2003.

2. Parameter lingkungan dalam air limbah pertambangan di lokasi A, C, D masih memenuhi KepMn LH 113 tahun 2003 lampiran 1.

\section{UCAPAN TERIMA KASIH}

Penulis mengucapkan terima kasih atas bantuan dan dukungan dari Ka.bidang Laboratorium Rujukan dan Pengujian: ibu Novy Farhani. Terima kasih juga atas kerjasama tim sampling pengkajian industri strategis dan tim analisis laboratorium air Pusarpedal- KLH.

\section{DAFTAR PUSTAKA}

(1) Undang-undang Republik Indonesia Nomor 32 Tahun 2009 tentang Perlindungan dan Pengelolaan Lingkungan Hidup. 2009.

(2) Keputusan Menteri Negara Lingkungan Hidup Nomor 113 Tahun 2003 Tentang Baku Mutu Air Limbah Bagi Usaha dan Atau Kegiatan Pertambangan Batu Bara. 2003.

(3) Standar Nasional Indonesia. Metode pengambilan air limbah, SNI 6989.59. 2008.

(4) American Public Health Association (APHA). Standard Methode for the Examination of water and wastewater 21st edition. American Public Health Association Washington DC, 2005.

(5) Andi Baso Tancung dan M.Ghufran H.Kordi K. Pengelolaan Kualitas Air Dalam Budi daya Perairan, Rineka Cipta. 2005.

(6) Badan Standarisasi Nasional. Kumpulan SNI (Standar Nasional Indonesia) untuk air dan air limbah. Badan Standarisasi Nasional. Jakarta, 2004.

(7) Hefni Effendi. Telaah Kualitas Air Bagi Pengelolaan Sumber Daya dan Lingkungan Perairan. KanisiusJakarta. 2003.

(8) Heryando Palar. Pencemaran dan Toxicologi Logam Berat. Rineka Cipta. 2004.

(9) H.R Mulyanto. Ilmu Lingkungan. Graha Ilmu. Jakarta. 2007.

(10) Japanese Standard Assosiation,. JIS Handbook Environmental Technology, 2002.

(11) Morton Lippmann, Environmental Toxicants, Wiley Interscience, second edition, 2000. 